\title{
RITUAL PENGUBURAN MAYAT SUKU SASAK DESA MONTONG BAAN SELATAN LOMBOK TIMUR
}

\author{
LALU NASRULLOH \\ Fakultas Tarbiyah, Institut Agama Islam Negeri (IAIN) Sorong \\ Laluarul90@gmail.com
}

\begin{abstract}
ABSTRAK
Penelitian dengan tema tradisi lokal sangat penting untuk dilakukan mengingat perkembangan zaman yang memaksa para agen budaya untuk melupakan tradisi daerahnya secara sadar maupun tidak sadar.Penelitian tentang tradisi lokal Sasak khususnya mengenai isu ritual penguburan mayit ini belum ada yang menelitinya, kalau pun ada hanya sebatas pengungkapan prosesi penguburan mayit secara umum yang dilihat dari kacamata agama.Sedangkan, yang terdapat di dalam penelitian ini merupakan pengungkapan unsur dan tahapan ritual adat dan keagamaan yang hanya ditemukan di sebagian kecil wilayah yang ada di Lombok Timur dan Lombok Tengah. Penelitian ini bertujuan untuk mendeskripsikan proses ritual penguburan mayit suku Sasak Desa Montong Baan Selatan, Lombok Timur, serta pengungkapan unsur-unsur budaya lokal yang terdapat di setiap tahapan ritual. Penelitian ini merupakan jenis penelitian deskriptif kualitatif.Temuan dalam penelitian ini berupa tahapan-tahapan pra penguburan berupa pembarak, tepong tanak, pemotongan bokos, pembuatan karang watang, dan sebagainya. Proses penguburan dilakukan dengan beberapa tahapan, seperti peletakan mayit, pembacaan talqin, pembacaan zikir dan doa, dan penyampaian kata-kata takziah. Pasca penguburan dengan tahapan sikir buka gumi, tahlilan, peraik kubur, dan sebagainya.
\end{abstract}

Kata Kunci: ritual; penguburan mayit; suku sasak;

\begin{abstract}
Research with the theme of local traditions is very important to be carried out considering the times that force cultural agents to forget their regional traditions consciously or unconsciously. Research on local Sasak traditions, especially regarding the issue of burial rituals of the deceased, has not yet been researched, if there is only just disclosure. The funeral procession of the deceased in general is seen from a religious perspective. Meanwhile, what is contained in this research is the disclosure of the elements and stages of traditional and religious rituals that are only found in a small part of the area in East Lombok and Central Lombok. This study aims to describe the process of the burial ritual of the deceased of the Sasak tribe in the village of Montong Baan Selatan, East Lombok, as well as to reveal the
\end{abstract}


elements of local culture found in each stage of the ritual. This research is a type of qualitative descriptive research. The findings in this study are in the form of pre-burial stages in the form of pemarak, tepong tanak, cutting bokos, making watang coral, and so on. The burial process is carried out in several stages, such as the laying of the deceased, reading the talqin, reciting dhikr and prayer, and conveying the words of takziah. After burial, with the stages of thinking about opening gumi, tahlilan, repairing graves, and so on.

Keywords: rituals; burial of the deceased; Sasak tribe;

\section{PENDAHULUAN}

Lombok merupakan daerah yang dikenal dengan semboyan 'Pulau Seribu Masjid'.Dari semboyan tersebut bisa dipastikan bahwa Lombok terdiri atas masyarakat yang mayoritas beragama Islam. Sejarah masuknya agama Islam di tanah Lombok pada abad ke-19 setelah Suaz Canal membangun dan banyak mengirim orang Sasak ke Mekah untuk menunaikan ibadah haji, dan sekembalinya mereka membangun masjid dan mendirikan sekolah yang beraliran Sunni ortodoks (Harnis, 2003). Selain sejarah yang dikatakan Harnis tersebut, keberadaan Islam yang diwarnai dengan tradisi-tradisi lokal seperti wayang, serakalan, dan proses penguburan mayit intidak terlepas dari peran ulama-ulama Jawa atau yang dikenal dengan istilah Wali Songo.

Sejarah juga mencatat bahwasanya Lombok pernah dikuasai oleh Bali yakni pada zaman-zaman kerajaan pembuktian sejarah tersebut bisa kita lihat dari peninggalanpeninggalan sejarah yang dapat dite Lombok Barat dan Kota Mataram.Sehingga, perpaduan budaya Islam Jawa dengan Hindu Bali sangat kental pada setiap aspek kebudayaan yang berkembang dan diyakini oleh sebagian besar masyarakat Sasak Lombok.Salah satunya adalah upacara adat dan tradisi pemakaman mayit.
Upacara adat yang terinternalisasikan di dalam proses pemakaman mayit (pra, proses, dan pasca) merupakan budaya yang memiliki nilai spritualitas yang tinggi. Nilai spiritualitas ini yang mesti selalu dipupuk dan dilestarikan sebagai bentuk masyarakat budaya yang tetap mengedepankan agama dalam pelaksanaan dan pelestarian kebudayaan.Upacara adat pada setiap prosesi penguburan mayit adat Sasak ini tentu selalu bersentuhan dengan ritual-ritual keagamaan.Ghazali (2011: 50) menyebutkan ritual-ritual keagamaan ini dengan istilah ritus.Ritus ini menurut Ghazali, adalah alat manusia religius untuk melakukan perubahan.Ia juga mengatakan sebagai simbolis agama, atau ritual itu merupakan agama dan tindakan.

Ritual-ritual keagamaan yang tercermin pada prosesi penguburan mayit adat Sasak ini merupakan adat dan tradisi yang diwariskan oleh nenek moyang Sasak secara turun temurun.Sehingga, hal ini menjadi sangat sakral bagi masyarakat Sasak secara umum.Saking sakralnya, setiap poin dalam prosesinya tidak boleh terlewatkan atau dilakukan dengan main-main, serta tidak boleh diubahubah apalagi dilewatkan.Hal ini dilakukan semata-mata untuk menghargai peninggalan para tetua adat terdahulu.Seperti halnya yang diungkapkan oleh Munawarroh (2016: 2) bahwa ritual-ritual ini telah menjadi 
tradisi dan menjadi bagian dari kehidupan sehari-hari sebagian masyarakat karena telah diwariskan secara turun-temurun oleh nenek moyang mereka kepada generasi berikutnya.

Eksistensi kebudayaan dan agama dalam setiap tradisi yang berkembang di masyarakat tidak terlepas dari pengakuan kuat dari para pelaku budaya.Sehingga dari pengakuan para pelaku budaya ini melalui konsistensi dan komitmen dalam melestarikan peninggalan nenek moyangnya telah memperkokoh eksistensi dari agama yang dianut oleh masyarakat adat setempat dikarenakan berbagai tradisi yang berkaitan dengan siklus kehidupan berkembang dan menjadi kuat ketika telah mentradisi dan membudaya di tengah kehidupan masyarakat, sebab esensi ajarannya sudah masuk dalam tradisi.Jadi, bukan sekedar "pepesan kosong" yang tidak memiliki isi dalam sanubari budaya masyarakat (Munawarrah, 2016).

Tradisi-tradisi tempatan yang berkembang pada suatu daerah yang sering disebut juga dengan istilah budaya lokal.Budaya lokal tentu juga mengandung nilai-nilai kearifan tempatan.Hartono (2015: 51) menyebutkan bahwa warna lokal atau budaya lokal merupakan ciri khas tertentu dari masyarakat setempat yang berkaitan dengan budaya tempatan. Maka, oleh masyarakat di daerah tersebut harus memiliki tanggung jawab untuk menjaga dan melestarikannya.

Selanjutnya, dalam budaya terdapat aspek atau unsur-unsur yang menjadi muatan kebudayaan tersebut.Salah satu unsur kebudayaan yang diungkapkan oleh Koentjaraningrat (1994: 11-12) adalah sistem religi atau kepercayaan.Sehingga, agama dan budaya dalam menjalani kehidupan bermasyarakat tidak bisa dipisahkan satu dengan yang lainnya. Karena agama dalam hal ini memiliki dua fungsi yakni fungsi manifest dan fungsi laten. Fungsi manifest, agama berkaitan dengan doktrin, ritual-ritual, dan aturan perilaku beragama. Sedangkan fungsi laten, agama berkaitan pergaulan sosial, mobilitas sosial, dan seperangkat nilai ekonomi (Harton dan Hunt, 1987: 327).

Di bangsa Indonesia ini sangat banyak daerah-daerah yang masih mempertahankan ritual-ritual keagamaan dan budaya yang telah diwariskan oleh nenek moyangnya. Sebut saja seperti Jawa, Sumatera Barat, Sulawesi Selatan, dan juga Lombok.Masyarakat Lombok masih kental dengan ritual-ritual keagamaan dan kebdayaan, seperti halnya ritual penguburan mayat.Aspek budaya yang tercermin dalam unsur kepercayaan/religi ini sudah sejak berapa abad dipraktikkan oleh para leluhur orang Lombok. Prosesi atau ritual agama penguburan mayat adat Sasak yang terdapat di Desa Montong Baan Selatan, Kecamatan Sikur, Kabupaten Lombok Timur ini merupakan bagian dari bentuk mempertahankan budaya lokal yang semakin hari semakin tergerus perkembangan zaman.

Ritual atau proses penguburan mayit adat Sasak ini merupakan ritual yang dianggap penting dan sakral sebagai bentuk penghormatan terhadap mayit dan penghiburan terhadap keluarga yang ditinggalkan. Di sisi lain ritual atau proses penguburan ini adat Sasak ini selain kental dengan unsur adat juga bagian dari mempraktikkan syariat agama, yakni memandikan, mengkafani, mensalati, dan menguburkan. Akan tetapi, selama proses berlangsungnya pengerjaan syariat tersebut masyarakat Sasak tentu tidak bisa berlepas diri dari aspek-aspek adat. Aspek-aspek adat 
dan ritual adat yang terinternalisasikan dalam kegiatan syariat agama inilah ayang akan dibahas oleh peneliti dalam penelitian ini.

Dari uraian di atas maka peneliti menggambarkannya dalam sebuah judul penelitian dengan judul Ritual Penguburan Mayit Suku Sasak di Desa Montong Baan Selatan Lombok Timur.

\section{METODE PENELITIAN}

Metode yang digunakan dalam penelitian ini adalah jenis deskriptif kualitatif.Metode ini bertujuan memberikan penjelasan mengenai fenomena yang terjadi di masa sekarang, serta menggambarkan secara sistematis, faktual, dan akurat mengenai fakta-fakta atau sifat-sifat dan hubungan antara fenomena yang diteliti. (Moloeng, 2007: 21).

Teknik pengumpulan data dalam penelitian ini dilakukan dengan beberapa cara sebagai berikut:

a. Wawancara

Langkah-langkah yang dilakukan peneliti dalam mengumpulkan data melalui wawancara sebagai berikut:

1) Melakukan wawancara terhadap terhadap pihak yang dianggap tokoh dan ahli dalam hal tradisi tersebut, dalam hal ini peneliti mewawancarai Lalu Sudirman dan Lalu Kamaruddin, M.Pd. Adapun jenis pertanyaan yang diajukan fleksibel namun tetap seputar permasalahan penelitian yakni tentang proses penguburan dan peralatan yang dipakai.
2) Proses wawancara dilakukan dengan santai dan terbuka dan dengan caa mencatat.

3) Data yang didapatkan kemudian dianalisis sesuai teknik analisis data yang digunakan.

b. Observasi

Observasi merupakan teknik pengumpulan data dengan cara melakukan pengamatan langsung terhadap objek yang diteliti. Dalam hal ini peneliti fokus mengamati semua proses penguburan mayit (pra, proses, pasca) dan segala bentuk peraltan yang dipakai.

c. Dokumentasi

Dokumentasi yang dimaksud untuk memperoleh data adalah dengan mendokumentasikan semua proses yang dilakukan, perkakas-perkakas budaya, dan peralatan yang disyariatkan agama (memfoto).

d. Studi Kepustakaan

Studi kepustakaan sebagai langkah tambahan dalam pengumpulan data, yakni dengan membaca literaturliteratur yang ada kaitannya dengan prosesi penguburan mayit dan ritual adat lokal.

Teknik Analisis Data yang digunakan peneliti dalam penelitian ini adalah analisis induktif, yaitu analisis diawali dengan melakukan wawancara/dokumentasi, pembahasan, bukti pendukung, dan diakhiri dengan simpulan.

\section{PEMBAHASAN}

Dalam keyakinan Islam terdapat tiga perkara rahasia Tuhan yang tidak akan diketahui oleh manusia, yakni kematian, rezeki, dan jodoh. Ketiga hal ini mutlak hak istimewa yang dimiliki oleh Allah Swt. Sebagai seorang manusia yang percaya terhadap takdir 
tersebut tidak boleh dianggap remeh, karena kejadiannya tidak diketahui kapan dan di mana.Tidak ada satu jiwa pun yang mampu menghindarinya (Djaelani, 2008: 50).

Bustanuddin mengungkapkan, kaum interialistis yang secara teoritis memahami kematian sebagai berhentinya proses fisik manusia kemudian semuanya berakhir dengan kehancuran (2006: 277).

Kematian oleh oleh sebagian besar manusia dianggap sebagai sesuatu yang sangat menakutkan karena kematian merupakan saat berpisahnya roh dengan jasad.Bagi masyarakat Sasak Lombok kematian ini sebagai wujud kehendak Allah yang harus diterima dengan ikhlas serta mesti dibarengi dengan rasa kekhawatiran yang tinggi.Sehingga, dalam mengiringi kematian seseorang selalu diadakan prosesi pengurusan dan perawatan jenazah, tentu dengan berpedoman pada syariat agama dan adat peninggalan nenek moyang.

Kematian itu sendiri bagi masyarakat Sasak dianggap sebagai sesuatu yang sakral disamping menakutkan.Dikatakan sakral, manusia yang meninggal dunia tersebut memiliki kewajiban untuk diurus sesuai adat dan agama yang diyakini. Sementara dalam tradisi masyrakat Sasak proses pengurusan jenazah dilakukan dengan penuh khidmat dan sangat sakral. Sehingga, ritual yang bernuansa dan memiliki nilai kesakralan ternyata terdapat tidak hanya pada ritual adat saja, melainkan terdapat juga pada ritual keagamaan.Eliade dalam (Rahmat, 2004: 22) mengatakan pada setiap kebudayaan selalu dikenal adanya sense of sacred, yang tercermin dalam ritus dan simbolnya.Inilah esensi dari agama.

Sense of sacredtersebut di atas tercermin pada prosesi pengurusan dan perawatan jenazah, tentu dengan berpedoman pada syariat agama dan adat-istiadat peninggalan nenek moyang.Sebagai warisan budaya yang diwariskan secara turun-temurun, sehingga dianggap sebagai suatu keharusan yang tidak boleh ditinggalkan, karena mereka sebagai pewaris kebudayaan memiliki kepercayaan terhadap adanya kekuatan gaib.Marzuki (2015: 1) mengemukakan perihal tersebut bahwa pelaksanaan upacara adat maupun ritual keagamaan yang didasari atas adanya kekuatan gaib masih tetap dilakukan oleh sebagian kelompok masyarakat di Indonesia, baik berupa ritual kematian, ritual syukuran atau slametan, ritual tolak bala, ritual ruwatan dan lain sebagainya.

Di sisi lain, prosesi penguburan suku Sasak yang berlandaskan syariat agama, meskipun di balik pelaksanaan berdasarkan syariat agama tersebut terselip ritual-ritual adat sebagai bentuk keyakinan masyarakat terhadap keberadaan kekuatan gaib. Hal ini juga menunjukkan keeksistensian agama atau keyakinan yang dianut oleh masyarakat setempat.Seolah mereka ingin berkata "inilah adat berlandaskan agama yang diwariskan oleh nenek moyang kami".Menyatunya tradisi dengan kehidupan menyebabkan masyarakat sebagai pelaku budaya dan penganut agama menjadi tak bisa terbantahkan oleh apapun. Seperti yang ungkapkan Munawarroh (2016: 3) bahwa adanya berbagai ritual dan tradisi yang dilakukan telah memperkokoh eksistensi dari agama yang dianut oleh masyarakatnya karena berbagai tradisi yang berkaitan dengan siklus kehidupan berkembang dan menjadi kuat ketika ia telah mentradisi dan membudaya di tengah kehidupan masyarakat.

Sehingga, masyarakat suku Sasak dalam hal melakukan upacara keagamaan maupun budaya, selalu 
mengedepankan sifat dasar sebagai makhluk ciptaanNya dan juga mesti kembali ke akar. Dalam arti, sebagai pelaku budaya dalam melakukan ritual harus berpedoman dengan apa yang diwariskan oleh nenek moyang, di setiap tahapan ritual. Karena hal ini sebagai wadah untuk memperkokoh keeksistensian masyarakat tersebut.Seperti pada pra penguburan mayit suku Sasak.Di setiap tahapan persiapan, dilakukan dengan penuh khidmat dan sakral.Mulai dari pembarak atau bebarak, yang harus dilakukan oleh orang dewasa, tidak boleh dilakukan oleh anak remaja.

Begitu pula dalam pelaksanaan tahapan tepong tanak, pembuatan karang watang, pemotongan books, dan lain-lain.Semua ini dilakukan sesuai upacara keagamaan yang berlaku di tempat tersebut.Karena diyakini memiliki tuah yang sangat besar apabila tahapan-tahapan tersebut tidak dilakukan sesuai dasar agama maupun adat.Upacara keagamaan sebagai wadah bagi masyarakat untuk mempertahankan keyakinan dan tradisi yang ada.Dalam hal ini upacara keagamaan, Narwoko et.al (2004: 254) menyebutnya ritus, artinya sarana bagi kelompok social untuk secara periodic mengukuhkan kembali dirinya.

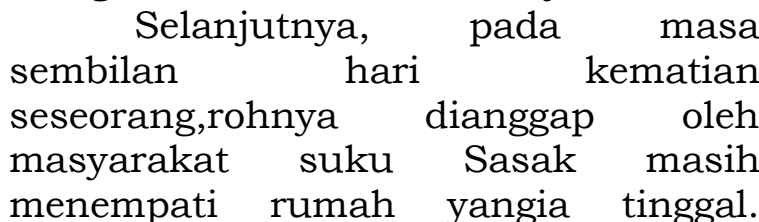
Maka, selama sembilan hari pasca penguburan mayit diadakan sikir pada malam harinya.Pada hari ketiga diselenggarakan yang namanya nelung.Pada hari ketujuh diadakan mituk dan hari ke Sembilan diadakan yang namanya nyiwak.Prosesi Sembilan hari tersebut diisi dengan doa-doa yang dikirimkan khusus kepada almarhum.
Bagi masyarakat suku Sasak selama masa Sembilan hari kematian seseorang dianggap rohnya masih menempati rumah yang ia tinggal selama masa hidupnya. Maka, selama Sembilan hari pasca penguburan mayit diadakan sikir pada malam harinya.Pada hari ketiga diselenggarakan yang namanya nelung.Pada hari ketujuh diadakan mituk dan hari ke Sembilan diadakan yang namanya nyiwak.Prosesi Sembilan hari tersebut diisi dengan doa-doa yang dikirimkan khusus kepada almarhum.

Selain nelung, mituk, dan nyiwak, di setiap sore selama sembilan hari prosesi pasca penguburan diadakan sikiran pajek pada dan peraik kubur di setiap subuh dan selesai asar.Sikiran pajek dan peraik kubur ini tidak lain adalah prosesi di mana pihak keluarga mengirimkan doa terhadap almarhum supaya diampuni segala dosa dan kesalahan selama masih hidup, diterima amal ibadahnya, dan di tempatkan di tempat yang terbaik di sisi Allah Swt. Sikiran pajek ini merupakan ritual zikir yang dilakukan oleh keluarga dekat saja tanpa mengundang masyarakat yang lain. Pajek dalam keyakinan masyarakat suku Sasak di desa Montong Baan Selatan merupakan sajian dalam bentuk dulang yang diperuntukkan untuk si mayit atau almarhum.Karena dianggap selama sembilan hari roh si mayit masih berada di rumah tempat tinggalnya.Sehingga, keluarga yang ditinggalkan menaruhkan sajian yang berisi nasi dan lauk pada sebuah wadah yang disebut dulang.

Keyakinan tersebut sepintas terkesan bergesekan dengan syariat, tetapi sekali lagi di sinilah adat dan tridisi berbicara yang apabila dilanggar pasti ada konsekuensinya. Kemudian peraik kubur, ritual ini merupakan rangkaian dari ziarah kubur yang dilakukan oleh keluarga si mayit untuk 
mengirimkan doa dan menyirami pusarannya. Demikianlah beberapa ritual doa dan zikir yang dilakukan oleh keluarga si mayit selama Sembilan hari pasca penguburan. Selanjunya peneliti akan membahas secara detil pra dan proses penguburan mayit suku Sasak yang ada di desa Montong Baan Selatan.

\section{Pra Penguburan}

Dalam prosesi pra penguburan mayit adat Sasak Lombok ini terdapat beberapa tahapan ritual yang dilakukan dan dilalui di antaranya sebagai berikut:

\section{Pembarakatau}

bebarak(pemberitahuan)

Dalam tradisi masyarakat sasak memberitahukan sanak keluarga tentang kematian dilakukan ritual bebarak atau memberitahukan. Memberitahukan ini dilakukan dengan cara menemui secara langsung keluarga yang dimaksud tanpa melalui telepon yang biasa dilakukan oleh sebagian masyarakat Sasak di zaman sekarang. Orang yang diberikan mandat untuk pergi memberitahukan terlebih dahulu dibekali tali tanda yang digantungkan di motor tau kendaraan yang dipakai pergi memberitahu. Tali tanda ini harus menggunakan pelepah pisang yang basah maupun yang kering. Sehingga, kalau terdapat tali pelepah pisang yang digantung dikendaraan apabila menemukan razia kendaraan oleh pihak kepolisian si pembarak (pemberitahu) ini tidak akan ditilang meskipun tidak dilengkapi dengan surat-surat dan tanpa memakai helm. Hal ini dikarena si pembarak dianggap sedang menjalankan adat dan tradisi yang berkembang di daerah tersebut.

Akan tetapi, ritual adat keagamaan tersebut sudah mulai luntur diakibatkan perkembangan teknologi informasi.Di zaman sekarang jarang ditemui hal demikian terkecuali di beberapa daerah yang masih mempertahankan tradisi, termasuk di wilayah desa Montong Baan Selatan.Kebanyakan sekarang hanya memanfaatkan telepon sebagai media pembarak, karena dianggap efektif dan praktis.Namun, pergeseran budaya tersebut menghilangkan kearifan lokal yang memiliki nilai silaturahim dan tata krama yang begitu tinggi. Maka, ritual keagamaan seperti bebarak tersebut tidak menutup kemungkinan tidak akan ditemui beberapa tahun kemudian.

\section{Tepong tanak}

Tepong tanak atau menggali liang lahat dilakukan dengan ritual yang bisa dikatakan sakral. Mulai dari orang yang melakukan tandaan atau menandai dan atau mengawali proses penggalian harus dilakukan oleh orang yang diyakini memiliki pengetahuan yang lebih di bidang agama dan memiliki doa tepong tanak. Sementara hanya beberapa orang saja yang memiliki doa tepong tanak ini. Berikutnya, kenapa dikatakan sakral proses tepong tanak ini harus terdapat andangandang. Andang-andang ini merupakan sebuah sajian yang berisikan beras, benang, lekok-lekes (sirih, apur, pinang, dan sebatang rokok pilitan), air dalam gelas, serta uang logam. Andang-andang ini wajib hukumnya ada pada setiap tahapan pra penguburan kecuali tahap bebarak.

Kenapa andang-andang ini diwajibkan pada setiap proses ritual adat dan keagamaan dalam pra penguburan tersebut?

1. Andang-andang merupakan tradisi orang Sasak sejak dulu 
2. Andang-andang memiliki makna pengusir makhluk jahat

3. Andang-andang memiliki makna sosial

4. Memiliki makna memberi dan berbagi

5. Memiliki makna kesederhanaan

6. Andang-andang menjadi persyaratan utama pada ritual-ritual adat tertentu.

Proses tepong tanak ini diawali dengan pembacaan doa oleh penandak tanak sembari memegang linggis yang digunakan untuk menggali. Lalu linggis tersebut dihujamkan ke tanah sebanyak tiga kali.Selanjutnya dilakukan penggalian oleh beberapa orang yang sudah ditugaskan. Adapun ukuran liang lahat juga tidak sembarangan, melainkan sesuai dengan ukuran mayit yang sudah diukur menggunakan tali yang terbuat dari pelepah pisang.

Berikut adalah dokumentasi yang peneliti dokumentasikan pada saat ritual tepong tanak dilakukan oleh tokoh agama sekaligus tokoh adat desa Montong Baan Selatan, atas nama Lalu Sudirman.

3. Pembuatan Karang Watang(keranda) Prosesi pembuatan karung watang atau keranda ini dilakukan dengan cukup khidmat.Tidak boleh dilakukan sambil bercandatawa.Selain itu, harus dilakukan di satu tempat, tidak boleh berpindahpindah tempat.Adapun bahan yang digunakan untuk membuat karang watang ini harus dari bambu tidak boleh menggunakan kayu apalagi
besi.Padahal di zaman sekarang di bebrapa tempat lebih-lebih di perkotaan karang watang ini menggunakan karang watang permanen yang terbuat dari besi.Namun, khusus di desa Montong Baan Selatang karang watang masih melestarikan tradisi yang ditinggalkan oleh nenek moyang yakni menggunakan bambu.

Cara pembuatannya pun sangat alot meski terlihat sederhana.Dimulai dari pemotongan dua batang bambu sebagai pelembah (pemikul), pengulatan (penganyaman) bambu yang sudah dibilah sebagai kerangkanya lalu diikat menggunakan benang.Terakhir, pembuatan payung karang watang yang terbuat dari bambu juga dan kain kafan sebagai atap payungnya. Selain itu, dalam proses pembuatan karang watang ini harus ada andang-andang.

Berikut dokumentasi yang peneliti ambil pada saat ritual pembuatan karang watang.

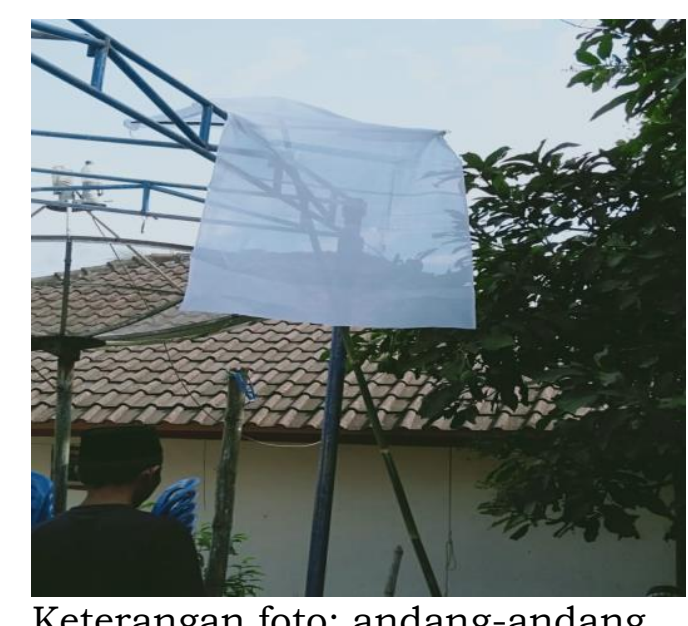

\section{Pemotongan bokos}

Pemotongan bokos (kain kafan) harus dilakukan oleh orang yang yang paham aturan syariat agama dan tentunya memahami aturan adat sesuai yang ditinggalkan oleh 
nenek moyang.Pemotongan bokos ini diselenggarakan di dalam ruangan tertutup dan juga harus terdapat andang-andang sebagai teman pengerjaan.

Di samping itu, orang yang memotong terlebih dahulu membaca doa khusus. Bokos atau kain kafan sengaja disimpan oleh sebagian besar kepala keluarga.Bokos ini juga tidak dibeli di Lombok maupun di Indonesia melainkan di Mekkah.Kain pembungkus mayit ini dipesan kepada keluarga yang mendapatkan kesempatan pergi menunaikan ibadah haki atau umrah. Dalam proses pemotongan bokos ini harus disertai dengan penaburan kapur barus dan wewangian di kain tersebut.

Berikut dokumentasi pemotongan bokos yang diambil oleh peneliti disaat prosesi pemotongan bokos.

\section{PenyembelihanPenurut}

(Penyembelihan Sapi)

Penyembelihan sapi di saat terdapat keluarga meninggal dunia ini yang disebut dengan penurut dilakukan sebagai bentuk penghormatan terakhir yang dilakukan oleh pihak keluarga terhadap si mayit.Dalam tradisi masyarakat Sasak ritual ini dipahami sebagai bentuk sedekah kepada para tamu (pelayat) yang datang belangar atau mendatangi tempat duka dengan membawa beras dan bahan pokok lainnya, atau ada juga yang membawa uang.

Penurut dengan bentuk penyembelihan hewan tersebut didasari oleh kondisi keuangan keluarga yang ditinggalkan.Menurut pengarek-arek (pesan peninggalan nenek moyang) penurut tidak wajib dalam budaya orang Sasak.Kalau mampu silahkan dilaksanakan sebagai bentuk sedekah untuk si mayit, tidak dilaksanakan juga tidak jadi masalah. Namun, yang menjadi masalah pemahaman yang berkembang di kalangan masyarakat Sasak khususnya di Desa Montong Baan Selatan, seolah-olah penurut itu wajib hukumnya meskipun pengadaannya dengan cara berhutang.

Padahal dalam syariat agama Islam, penurut itu diartikan sebagai akikah.Bila si mayit pada saat dilahirkan dulu (saat akikah) tidak disembelihkan hewan kurban baik hewan sapi atau pun kambing, maka dianjurkan ketika meninggal disembelihkan hewan sebagai pengganti akikahnya.Akan tetapi, pandangan masyarakat di Desa Montong Baan Selatan tidak mengganggap penurut itu sebagai bentuk pengganti akikah melainkan sebagai bentuk penghargaan dan sedekah bagi si mayit sekaligus diniatkan sebagai jamuan untuk para pelayat yang datang dari jauh.

Berikut dokumentasi yang peneliti ambil pada saat proses penyembelihan hewan sebagai penurut si mayit.

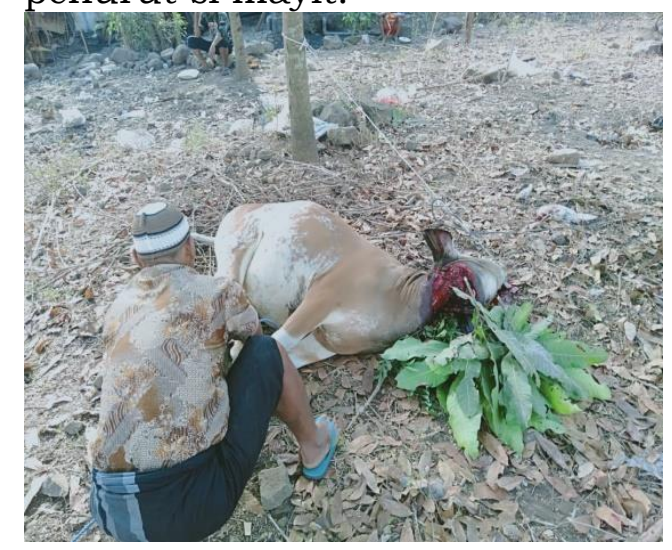

Keterangan foto: hewan penurut setelah disembelih

\section{Pelangar}

Pelangar merupakan bahan pokok berbentuk beras, gula, kopi, mie, minyak, dan lain sebagainya 
yang dibawa oleh orang yang datang malayat ke rumah duka. Dalam tradisi masyarakat Sasak belangar (melayat) merupakan wujud kepedulian antar sesame dalam kondisi berduka.Belangar ini juga sebagai pembuktian bahwa masyarakat Sasak memiliki tradisi yang luhur dalam hal kebersamaan dan tolong-menolong.

Hasil pelangar ini dipakai untuk memenuhi kebutuhan selama proses tahlilan, nelung, mituk, dan nyiwak pasca penguburan. Selain itu sisa pelangar setelah dipakai untuk memenuhi kebutuhan selama prosesi tahlilan, nelung, mituk, dan nyiwak akan disedekahkan untuk si mayit dan juga ada yang menyisakan untuk keperluan pelayaran /zikir mingguan setelah selesai pelaksanaan ruah Sembilan hari, empat pulu/empat puluh hari.

7. Memandikan Mayit

Proses pemandian jenazah ini dilakukan sebagaimana orang biasa melakukan. Dalam artian tidak ada ritual khusus kalau di dalam proses pemandian jenazah ini. Prosesi ini dilakukan sesuai syariat.

8. Menyolatkan

Sebagaimana proses pemandian jenazah, dalam proses menyolatkan jenazah juga dilakukan berdasarkan syariat sesuai ahlussunah waljamaah.

\section{ProsesPenguburan}

Setelah melewati proses pra penguburan/ persiapan penguburan, selanjutkan dilaksankan penguburan atau orang Sasak menyebutnya dengan istilah betalet/betukak. Betalet ini dilakukan setelah selesai prosesi penyolatan jenazah yang dilaksanakan di masjid terdekat. Proses penguburan ini dilaksankan dengan beberapa tahapan.

Pertama, disaat peletakan mayit di liang lahat diiringi dengan pembacaan ayat-ayat pendek. Kedua, setelah selesai peletakan mayit dan penimbunan liang lahat dilanjutkan dengan pembacaan talqin. Ketiga, dilanjutkan dengan pembacaan zikir dan doa. Keempat, sambutan atas nama keluarga. Kelima, penyampaikan kata-kata takziah oleh tuan guru atau kyai.

\section{Pasca Penguburan}

Pasca penguburan jenazah, bagi tradisi masyrakat Sasak dilanjutkan dengan berbagai jenis acara sebagai berikut:

1. Zikir Pembuka Gumi (bumi)

Zikir pembuka gumi ini dilakukan sepulang keluarga dari kuburan setelah selesai prosesi penguburan jenazah.

2. Tahlilan

Tahlilan bagi tradisi masyarakat Sasak dilakukan seperti halnya masyarakat ahlussunah waljamaah lainnya. Tahlilan atau pembacaan zikir dan doa yang diperuntukan khusus untuk si mayit yang dilaksanakan selama sembilan hari dan diselenggarakan pada malam hari, serta mengundang banyak jamaah.

3. Peraik Kubur

Peraik kubur atau ziarah kubur dilakukan oleh pihak kelurga yang ditinggalkan.Ritual ini lakukan dua kali sehari, yakni pada pagi hari dan sore hari selama sembilan hari.

4. Sikiran Pajek

Sikiran pajek merupakan tradisi yang berkembang sejak nenek moyang orang Sasak terdahulu.Sikir pajek ini dilakukan dua kali sehari, yakni pada pagi dan sore hari. Zikir dan doa dalam sikiran pajek ini diperuntukkan untuk si mayit.

5. Nelung, Mituk, dan Nyiwak

Nelung, mituk, dan nyiwak merupakan tradisi yang berkembang di daerah Sasak.Ritual ini dilaksanakan pada hari ke tiga, ke 
tujuh, dank e Sembilan hari atas kematian si mayit.Dalam ritual ini para keluarga dekat almarhum berdatangan seperti halnya datang pesta.Para tamu datang membawa bende atau bawaan berupa bahan pokok (beras, gula, minyak, dsb) dan para tamu dijamu dengan makanan pokok.

6. Pelayaran

Pelayaran atau zikir dan doa yang dilakukan pasca nyiwak. Ritual ini diselenggarakan sampai jatuh hari acara puluh hari di setiap hari kematian almarhum.

7. Empat Pulu (empat puluh hari)

Ritual empat pulu adat Sasak ini dilakukan dengan roah/ acara pembacaan zikir dan doa bagi si mayit pada hari ke empat puluh pasca meninggalnya si mayit dengan mengundang banyak keluarga (lakilaki dan perempuan).

8. Nyatus (seratus hari)

Seperti halnya empat pulu di atas, ritual nyatus ini juga merupakan kegiatan roah yang dilakukan oleh pihak keluarga untuk si mayit pada hari ke seratus.

9. Legong

Legong merupakan kondisi di mana kuburan si mayit sudah berusia lama antara dua atau tiga tahun.Kondisi ini ditandai dengan berlubangnya kuburan si mayit.Pada momen ini pihak keluarga mengadakan roah lagi dengan mengundang banyak kelurga sekaligus memperbaiki kondisi fisik kuburan yang sudah berlubang.

\section{PENUTUP}

Simpulan

Penelitian ini dilakukan sebagai bentuk kepedulian peneliti dalam memandang kondisi tradisi lokal yang ada di Desa Montong Baan Selatan Kecamatan Sikur Kabupaten Lombok Timur.Ritual penguburan atau pemakaman mayit adat Sasak Lombok ini penting untuk bahas sekaligus sebagai media menginkubasikan kebudayaan tempatan ini.

Sehingga, di dalam penelitian ini ditemukan beberapa unsur kebudayaan, seperti kepercayaan, perkakas budaya, pendidikan, mantra dan doa. Unsur-unsur tersebut tercermin pada hasil penelitian, yaitu pra, proses, dan pasca penguburan.

Pra penguburan terdapat beberapa tahapan di antaranya pembarak, tepong tanak, pembuatan karang watang, pemotongan bokos, penyembelihan penurut, pelangar, memandikan mayit, dan menyolatkan. Proses penguburan dilakukan dengan beberapa tahapan seperti peletakan mayit sampai penimbunan yang diiringi dengan pembacaan ayat-ayat Al-Quran, pembacaan talqin, pembacaan zikir dan doa, sambutan atas nama keluarga, dan penyampaian katakata takziah oleh tuan guru. Pasca penguburan dilalui dengan tahapantahapan berikut, yakni zikir pembuka gumi, tahlilan, peraik kubur, nelung, mituk, nyiwak, pelayaran, empat pulu, nyatus, dan legong.

\section{Saran}

Penelitian sederhana ini sekiranya bisa dijadikan sebagai acuan bagi peneliti, akademisi, dan pemerhati budaya untuk menciptakan isu-isu penelitian etnohistoris lainnya.Sehingga, pengembangan keilmuan budaya khususnya budaya lokal terus hidup dan berkembang dan bisa berkontribusi sebagai jawaban atas permasalahan-permasalahan yang timbul di tengah masyarakat budaya. 


\section{DAFTAR PUSTAKA}

Agus, Bustanuddin. (2006). Agama dalam Kehidupan Manusia. Jakarta: Raja Grafindo Persada

Djaelani, M. B. 2008. Indahnya Kematian. Yogyakarta: Insani Madani

Ghazali, Adeng Muchtar. (2011) Antropologi Agama. Bandung: Alfabeta.

Harnis, David. (2003). World of Wayang Sasak: Music, Performance, and Negotiations of Religion and Modernity. Asian Music, $34,2,91$.

Hartono (2015).Warna Lokal Jawa dalam Novel Indonesia Periode 1980-1995. Disertasi Doktor, Universitas Gadjah Mada.

Hurton, Paul B. dan Hunt C.L. (1991) Sosiologi. Jakarta: Erlangga. Jild II.
Koentjaraningrat.(1994). Kebudayaan, Mentalitas dan Pembangunan. Jakarta: Gramedia Pustaka Utama.

Marzuki, Nur Najman. (2015) Simbolisme dalam Upacara Adat: Kajian terhadap Upacara Adat Moppogau Hanua pada Masyarakat Adat Karampuang di Kabupaten Sinjai, Sulawesi Selatan, tesis, Sekolah Pascasarjanan Universitas Gajah Mada.

Munawarroh, Alvina. (2016) Fungsi Sosial Tradisi Mandoa dalam Upacara Kematian (Studi: Nagari Pauh Duo Nan Batigo, Kecamatan Pauh Duo, Kabupaten Solok Selatan). Diploma thesis, Universitas Andalas.

Narwoko, J. Dwi dan Bagong Suyanto. (2007). Sosiologi: Teks Pengantar dan Terapan. Jakrta: Kencana

Rahmat, Jalaluddin. (2004). Psikologi Agama. Bandung: Mizan. 